\title{
Water pollution: one of the main Limnology challenges in the Anthropocene
}

\author{
Poluição hídrica: um dos principais desafios da Limnologia no Antropoceno
}

\author{
Gabrielle Rabelo Quadra ${ }^{1 *}$ (D), José Reinaldo Paranaíba Vilela Alves Teixeira ${ }^{1}$ (D), \\ Nathan Barros ${ }^{1}$ (D), Fábio Roland ${ }^{1}$ (D) and André Megali Amado ${ }^{1,2}$
}

\begin{abstract}
'Programa de Pós-graduação em Ecologia, Laboratório de Ecologia Aquática, Departamento de Biologia, Universidade Federal de Juiz de Fora, Rua José Lourenço Kelmer, Campus Universitário, Bairro São Pedro, CEP 36036-900, Juiz de Fora, MG, Brasil

${ }^{2}$ Departamento de Oceanografia e Limnologia, Centro de Biociências, Universidade Federal do Rio Grande do Norte, Via Costeira, Praia de Mãe Luiza, CEP 59014-002, Natal, RN, Brasil

*e-mail: gabrielle.quadra@ecologia.uff.br
\end{abstract}

Cite as: Quadra, G.R. et al. Water pollution: one of the main Limnology challenges in the Anthropocene. Acta Limnologica Brasiliensia, 2019, vol. 31, e203.

Abstract: Humankind is defining a new geological time. The Anthropocene epoch is marked by changes in the geological processes, hydrological regimes, biosphere structure, among other processes, due to human expansion over the landscape worldwide. Biogeochemical cycle's acceleration, the high load of pollutants in water resources, rampant deforestation, increase in the greenhouse gas emissions to the atmosphere, eutrophication and biodiversity losses are some indications that reflect human's pressure over several ecosystems, especially aquatic ones. Therefore, here we reviewed some aspects from a huge anthropogenic influence on ecosystems: water pollution. For decades, humankind has increasingly placed demands on aquatic environments without any concern. As an effect, lakes, rivers, and reservoirs are being globally degraded. Although the interactive effects of future anthropic processes are complex, much of current knowledge suggests that these pressures are likely to increase in magnitude and frequency over the next years. Hence, scientific results need to be articulated in an integrative perspective to expand our understanding of the aquatic resources management. The ecological knowledge generated by scientists must be applied to solve environmental problems enabling human progress sustainably. It is urgent to improve communication and understanding among different sectors of society in favor of water management. Therefore, it will be possible to ensure the preservation of natural resources for future generations by using transdisciplinary tools to understand, mitigate and recover the water resources from these anthropogenic pressures.

Keywords: aquatic ecosystems; biogeochemical cycles; eutrophication; pollutants.

Resumo: A humanidade está definindo um novo período geológico. A era do Antropoceno é marcada por mudanças nos processos geológicos, nos regimes hidrológicos, na estrutura da biosfera, dentre outros processos devido às expansóes humanas sobre a paisagem ao redor do mundo. A aceleração dos ciclos biogeoquímicos, a grande carga de poluentes nos recursos hídricos, o desflorestamento desenfreado, o aumento das emissóes de gases de efeito estufa para a atmosfera, a eutrofização e a perda da biodiversidade são algumas evidências que refletem as pressóes humanas sobre diversos tipos de ecossistemas, especialmente os ecossistemas aquáticos. Desta maneira, neste estudo nós revisamos alguns aspectos da grande influência antrópica sobre os ecossistemas: a poluição hídrica. Durante décadas, a humanidade tem colocado cada vez mais demandas sobre os ambientes aquáticos sem qualquer 
preocupação. Como efeito, lagos, rios e reservatórios estão sendo degradados globalmente. Embora os efeitos interativos dos processos antrópicos futuros sejam complexos, muito do conhecimento atual sugere que essas pressóes provavelmente aumentaráo sua magnitude e frequência nos próximos anos. Consequentemente, os resultados científicos precisam ser articulados em uma perspectiva integradora buscando expandir o nosso entendimento sobre o manejo dos recursos hídricos. $\mathrm{O}$ conhecimento ecológico gerado pelos cientistas deve ser aplicado para solucionar os problemas ambientais permitindo o progresso humano de uma forma sustentável. É urgente a melhora da comunicação entre diferentes setores da sociedade em prol do manejo dos ecossistemas aquáticos. Assim, será possível garantir a preservação dos recursos naturais para futuras geraçóes aplicando ferramentas transdisciplinares para entender, mitigar e recuperar os recursos hídricos destas pressóes antropogênicas.

Palavras-chave: ciclos biogeoquímicos; ecossistemas aquáticos; eutrofização; poluentes.

\section{Introduction}

Human activities have profoundly altered ecosystems worldwide creating a new geological epoch, known as Anthropocene (Griggs et al., 2013; Steffen et al., 2007; Steffen et al., 2011). The Anthropocene is divided into three periods: "The Industrial Era (1800 - 1945)", "The Great Acceleration (1945 - 2015)", and "Stewards of the Earth System (2015 - ?)" (Steffen et al., 2007). The indications for this new epoch are many, such as population growth, deforestation, changes in biogeochemical cycles, climate and environmental changes, hydrological regimes modifications, increases in greenhouse gases emissions, environmental pollution, biodiversity loss, among others. The period known as "Stewards of the Earth System" is a signature of human knowledge on such anthropic impacts. Moreover, it highlights the time to develop strategies to support life on Earth in face of many stressors (Griggs et al., 2013; Steffen et al., 2007; Steffen et al., 2011).

Despite warnings from researchers about anthropogenic pressures on ecosystems worldwide, which it may be exceeding the Earth's support capacity (UCS, 1992), it seems that most of the 'decision-makers' over the globe still do not care or take concrete actions to halt or revert global changes. As a consequence, new warnings continue to come up over and over, pointing out the same problems above-mentioned (Ripple et al., 2017; Rockström et al., 2009). For instance, a recent alert has just come out exposing the need for more care on the management of wetlands (Finlayson et al., 2018). For lakes, reservoirs, and rivers, the challenges are the same. Freshwater ecosystems sustain many kind of life and play key roles in the cycling of matter and energy (Cardoso et al., 2019; Cole et al., 2007; Tranvik et al., 2009). Therefore, it is undoubted that humankind depends on watercourses due to ecosystem services provided, such as climate regulation, purification process, watering, and food production (Ray, 2011; Schwarzenbach et al., 2010). Despite its importance, aquatic ecosystems have been suffering great deteriorations, compromising the water quality and availability (Smith et al., 2006; Smith $\&$ Schindler, 2009; Schwarzenbach et al., 2010).

The impacts on aquatic ecosystems are numerous, and among them, we can highlight the disposal of not-properly treated effluents, resulting in chemical pollution and eutrophication (Schwarzenbach et al., 2010), in which make the limnological challenges more complex. Accordingly, here we compile knowledge available in the literature about one of the major anthropogenic influences that are affecting ecosystem worldwide: water pollution. We described the main causes and consequences of water pollution as well as ways for mitigation. In addition, we have gathered some examples of chemical contamination in the Brazilian aquatic ecosystems through a literature review.

\section{Eutrophication}

The nutrient enrichment, or eutrophication, have greatly increased since the industrial revolution, and human activity has profoundly altered the global cycles of nitrogen $(\mathrm{N})$ and phosphorus (P) in aquatic environments (Smith et al., 1999; Vitousek et al., 1997). The external inputs of $\mathrm{N}$ and $\mathrm{P}$ into the aquatic environments come from several sources, including groundwater, leaching, untreated and partially treated sewage, agriculture runoff, atmospheric deposition and/or fixation, among others. Many studies indicate that eutrophication related to human population growth has triggered the occurrence of harmful algal blooms in aquatic environments around the world (Anderson et al., 2002; Hallegraeff, 1993; Heisler et al., 2008). However, the harmful algal blooms are characterized by a complex event, which is not caused by a single environmental change but rather by multiples factors occurring synergistically 
(Heisler et al., 2008). This phenomenon implies the deterioration of water resources, which have direct and indirect effects on the global economy, as well as human and environment health. Some aspects of eutrophication are characterized by shifts in the composition of non-toxic phytoplankton species to toxic ones, increasing of the $\mathrm{pH}$, oxygen depletion, fish mortality, reduction in water transparency, changes in the aesthetic value and odor, among others (Smith et al., 1999).

As the eutrophication problem has been studied for several years, some practical approaches have been applied in experiments from microcosm to whole-ecosystems scales, to reverse the eutrophication. For instance, mineral compositions have been applied into lakes to immobilize $\mathrm{P}$ in the sediment (for details, see Zamparas \& Zacharias 2014). These techniques are succeeding in many locations, according to short-term studies. However, it is still unclear how its long-term applications may compromise the aquatic ecosystem health. Besides that, it has also been tested the efficiency of performing trophic manipulations to reduce eutrophication, i.e., to reduce internal nutrients upwelling from the sediments to the water column in shallow tropical lakes. For example, the replacement of a benthivorous native fish by an invasive planktivorous fish (Nile tilapia) has shown significant reduction of $\mathrm{P}$ release from the sediment to the water column in mesocosm experiment performed in a tropical eutrophic semi-arid reservoir. As a consequence, a reduction in the phytoplankton biomass was observed, restoring transparency conditions (Dantas et al., 2019). Therefore, one critical tool to mitigate eutrophication in aquatic ecosystems is to control nutrient loads, mainly N and P (Carpenter, 2008; Schindler et al., 2008). Thus, there are examples of possible management actions that can be important tools to mitigate eutrophication and restore aquatic ecosystems services.

\section{Chemical Pollution}

Industrial development and uncontrolled urbanization lead to land cover change, soil erosion, and waste production. These impacts trigger chemical loads into the water bodies, in which metals and organic pollutants have a prominent place due to their capacity to alter the ecosystems functioning, quality and steady-state (Filser, 2008; Förstner \& Wittman, 1983; Harrad, 2009; Reemtsma \& Jekel, 2006; Welch, 2002).

\subsection{Metals overview}

Metals (e.g. cadmium, chromium, zinc, copper, lead) may represent a direct risk to human and environmental health depending on environmental concentrations (Förstner \& Wittman, 1983). Metals have natural and anthropic sources to the freshwater ecosystems. Among the natural sources, mineral weathering of rocks and soils are the most important ones (Förstner \& Wittman, 1983; Salomons \& Förstner, 1984). Anthropogenic sources include smelting processes, fuel combustion via atmospheric deposition and waste discharges (Förstner \& Wittman, 1983; Salomons \& Förstner, 1984). In addition to these sources, mining waste can also cause huge ecological damages, even more if there is a dam failure (Segura et al., 2016; Hatje et al., 2017; Quadra et al. 2019a). Clearly, this type of accident should not happen and the safety of tailings dams needs to be improved with greater investments (Lopes et al., 2019). Aquatic communities are continually exposed to metals due to their continuously dumping into the environment, and humans are exposed to these metals through lifelong drinking water consumption. Accordingly, the emission and the accumulation of metals in aquatic ecosystems need to be appropriately addressed by society since they affect growth, reproduction and cause genotoxic effects on all life forms depending on their concentrations (Hadjiliadis, 2012; Moore \& Ramamoorthy, 2012; Mason, 2013).

\subsection{Organic pollutants overview}

The group of organic pollutants includes compounds that present a combination of carbon, hydrogen, oxygen, nitrogen, sulfur and the halogens (e.g. fluorine, chlorine, bromine, iodine) in their molecular formulas. They present an enormous complexity of molecular structures, and here we will discuss about some of those groups.

\subsubsection{Pharmaceuticals and Personal Care Products (PPCPs)}

The intensification of medicines production and consumption makes pharmaceuticals and personal care products (PPCPs) an environmental concern (Locatelli et al., 2011; Quadra et al., 2017a). Some aggravating factors on PPCPs pollution are self-medication, inversion of the population pyramid and the improper discarding (Daughton \& Ruhoy 2013; Quadra et al., 2017a; Quadra et al., 2019b). Most PPCPs pass through water and sewage treatment plants and are not completely removed. As a result, PPCPs may end up 
in aquatic ecosystems (Tambosi et al., 2010) and are seldom required by regular water quality guidelines. Once in the aquatic environment, PPCPs may cause ecotoxicological effects on the biota and reach humans through drinking water or food consumption (Monteiro et al., 2016). It is alarming the magnitude of concentrations, such as those derived from pain killers and hormones, which have been found in natural aquatic ecosystems. It is worth to emphasize the potential chronic effects caused by their exposures, since hormones, antidepressants, and antibiotics have already been tested and the results suggest changes in growth rates, behavior, and reproduction of aquatic organisms, which may lead to profound changes in the ecological structure of aquatic ecosystems (Doerr-MacEwen \& Haight, 2006; Kümmerer, 2008). Thus, the chronic effects can be or become a health issue in a near future and it is urgent to better understand the role and fate of these contaminants in the water, aquatic organisms and humans (Brausch et al., 2012).

\subsubsection{Pesticides}

The application of pesticides in agriculture is an inefficient process, given that only a small fraction of the amount-applied pesticide is retained by the crops. Then, farmers end up applying even more pesticides to increase its absolute retention, resulting in more residues to flow throughout the land (runoff) into aquatic ecosystems (Matthews, 2015). As a consequence, contamination of surface water and groundwater by pesticides is a worldwide reality (Cerejeira et al., 2003; Ritter, 1990; Turgut, 2003). Pesticides residues have already been found in drinking water in several countries, and even in the fat and milk of humans (Carlile, 2006). Several non-target organisms are affected by the indiscriminate use of pesticides, and negative effects have already been described for bees, earthworms, arthropods, aquatic invertebrates, fish, amphibians, reptiles, birds, and mammals (Carlile, 2006). The widespread use of DDT, for example, was responsible for the population decline of birds, among them, the US symbol, the bald eagle (Haliaeetus leucocephalus - Linnaeus, 1766) (D’Amato et al., 2002).

\subsubsection{A few more examples}

Obviously, organic pollutants are not limited to PPCPs and pesticides. Some pesticides, for example, are included in the list of persistent organic pollutants (POPs). POPs are of great concern, because they are stable and persist in the environment for long periods. In addition, they present a great tendency for bioaccumulation, have high toxicity, and are transported over long distances (Harrad, 2009; Reemtsma \& Jekel, 2006). The Stockholm Convention aims to protect human health and the environment from those chemicals (Stockholm Convention, 2019), but many of them are not yet on the list to be eliminated or have the use reduced. Researchers face a real challenge to understand the fate and effects of these compounds on humans and in the environment (Sobek \& Undeman, 2019).

Polychlorinated biphenyls (PCBs), for example, are compounds that have many industrial applications, such as cooling substances for electrical apparatus, and its biomagnification is a great issue for some organisms, such as polar bears, fishes and even humans (Pavlova et al., 2016; Sobek et al., 2006). Polycyclic aromatic hydrocarbons (PAHs) are well-studied compounds, which are presented in the aquatic environment by effluents and atmospheric deposition and may alter the reproduction and development of organisms (Abdel-Shafy \& Mansour, 2016). Brominated flame retardants (BFRs) are used to decrease material flammability and their main environmental sources are the diffusive leaching from households and industries. Humans are exposed to BFRs by indoor air and even household dust (for details see Wit (2002) and Harrad (2009)). Perfluoroalkyl compounds (PFAs) have a huge industrial application in different materials to create resistance for water, stain, oil, among others. PFAs reach the environment by direct disposal, spills and releases during production and application (for details see Ahrens (2011) and Harrad (2009)). Dioxins and furans are known for their toxicity and they are by-products of the manufacturing other chemicals and are being released into the environment by incineration reactions (for more details see Fletcher and McKay, 1993 and Harrad, 2009). Therefore, organic pollution is a vast area of research that needs more investment to understand their interactions within the environment.

\section{Probably, the Biggest Challenge: Multiple Stressors}

We present here some examples of water pollution, but it is important to keep in mind that the number of existing industrial products is huge. Therefore, it is noteworthy to think that there is a combination of such pollutants in the environment. Aquatic ecosystems are exposed to a pool of various 
pollutants (Sobek \& Undeman, 2019). How to consider the different exposures that aquatic ecosystems are facing, such as eutrophication and chemical pollution? For chemical pollution, mixtures effects have already been demonstrated and the existence of synergies is unquestionable (Chu \& Chow 2002; Cleuvers, 2003, 2004; Mejía-Saavedra et al., 2005; Fleeger et al., 2007; Qian et al., 2009). However, how can we deal with these huge pollutant varieties that present different chemicals structures and their behavior in the environment?

Here we put together few examples of chemicals in Brazilian ecosystems to show how they are usually found in the aquatic environment. Typically, metals are found in higher magnitude in the aquatic ecosystems than pesticides and PPCPs, respectively (Figure 1). Moreover, generally, metals presented higher concentrations in sediments than surface water, as well as pesticides, while PPCPs are hydrophilic (Figure 1).

The ecotoxicological data may give a misinterpretation that those concentrations may not pose a risk to aquatic organisms (Figure 1). However, for all the compounds is important to consider long-term and mixture effects, since different chemicals are continuously discharged in the environment. Then, studies considering the complex mixtures of chemicals are crucial for water quality criteria to protect organisms adequately (Salomons and Förstner, 1984; Sobek \& Undeman,
2019). Moreover, different species exhibit different tolerances and some end-points are more sensitive, such as behavior. All these variabilities should be take into account.

\section{What Shall We Do, Then?}

Considering the Anthropocene epoch and its causes and consequences, modern limnology faces challenges and needs to dedicate efforts to understand the ecological implications of multiple stressors in the aquatic ecosystems. The demand for water is rising, while the number of residues produced grows in the same constancy. So, first of all, we need to re-evaluate where and how we dispose of our residues, since, with the increasing demand for water quantity and quality, it is contradictory to the unsustainable use of water resource. All our waste end up in the aquatic ecosystems and we use the same water for supply and irrigation, a big counter-census (Figure 2).

There are several personal and collective attitudes that can also help to reduce the anthropogenic impacts on water resources, such as collaborative consumption, organic food production, law enforcement for reverse logistics, restric fertilizers and pesticides use in watersheds, control groundwater uses, investment in technology for other energy sources and pollutants removal in treatment plants, green products, among others (Abdel-Shafy \& Mansour, 2016; Anastas et al., 2000; Griggs et al., 2013; Pereira et al., 2017; Quadra et al.,

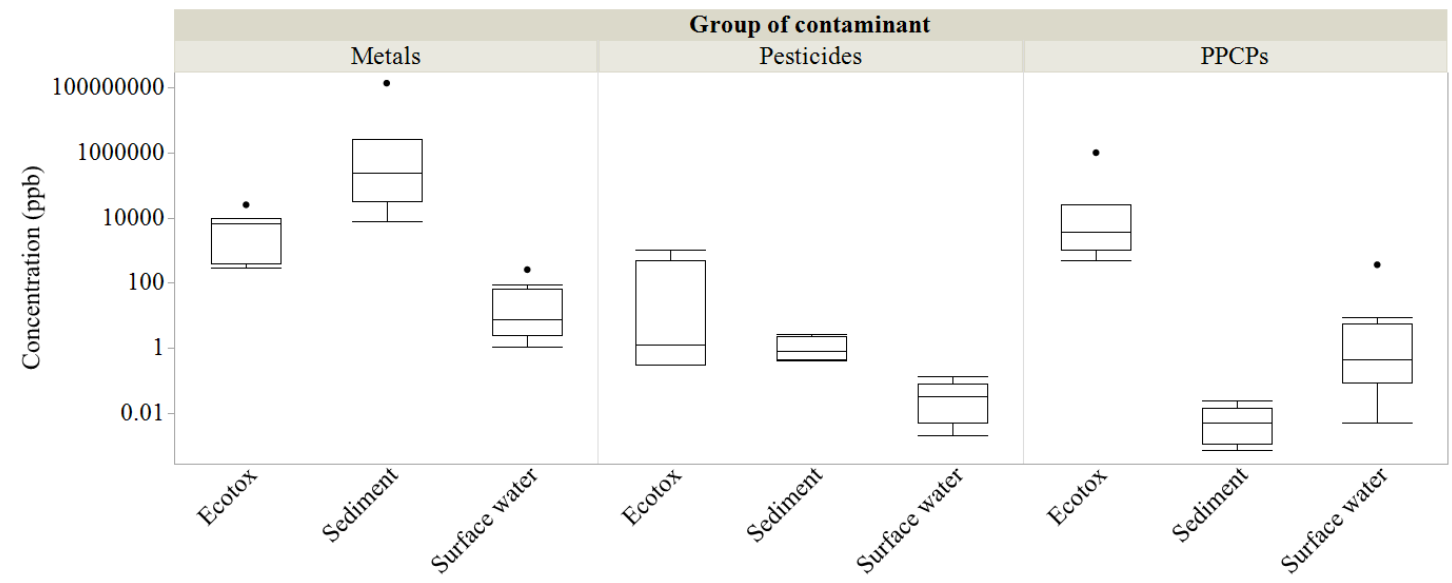

Figure 1. Concentrations of metals, pesticides and pharmaceuticals and personal care products (PPCPs) in the Brazilian aquatic ecosystem and ecotoxicological data. Sources: Almeida \& Weber (2009); Alves et al. (2014); Beretta et al. (2014); Bonai et al. (2009); Brix et al. (2011); Costanzo et al. (2005); Ferreira (2005); Ghiselli (2006); Gibson et al. (2009); Gonçalves (2016); Han et al. (2010); Imai et al. (2005); Kim et al. (2012); Koprivnikar \& Walker (2011); Kouyoumjian \& Uglow (1974); Laabs et al. (2002); Lee et al. (2011); Liao et al. (2003); Locatelli et al. (2011); Montagner \& Jardim (2011); Montagner et al. (2014); Monteiro et al. (2016); Oliveira et al. (2009); Partridge \& Lymbery (2009); Pascoe et al. (2002); Pereira et al. (2016); Pestana et al. (2007); Pickering et al. (1962); Devi Prasad \& Devi Prasa (1982); Rissato et al. (2006); Sanders et al. (1981); EPA (2007). 


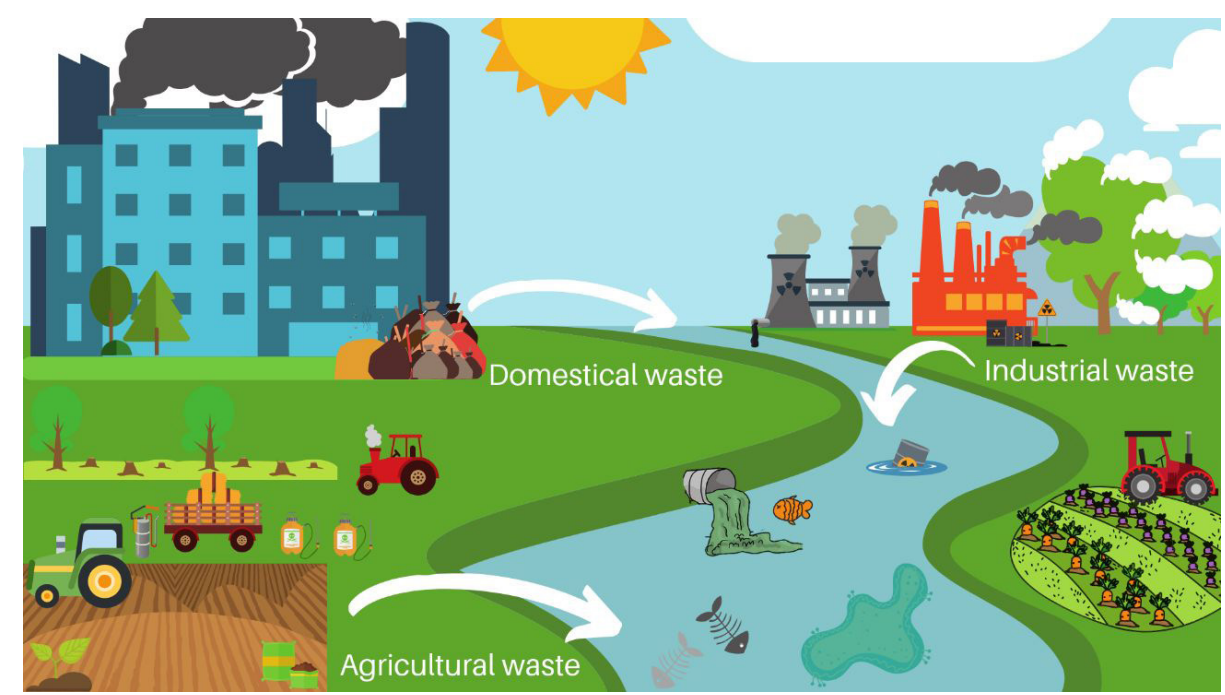

Figure 2. Different sources of chemicals to aquatic ecosystem.

2017a; Quadra et al., 2017b; Steffen et al., 2007; Steffen et al., 2011). The implementation of pollution prevention is also crucial. Pollution prevention reduces the generation of pollutants and wastes, prioritizing recycling and treatment, and minimize the use of harmful products, which includes more restrictive and effective laws on their regulations (Mulholland \& Dyer 2010).

The challenges to preserve the water quality in ecosystems are many and includes the need for transdisciplinary work, such as the reforestation of riparian zones with native species and investment in environmental education and social programs (Tundisi, 2005). However, it is truly necessary to improve the communication and action among different sectors of the society (Sobek \& Undeman, 2019), so that mutual attitudes can be taken, since we have the same propose: preserve water. For instance, the Brazilian water legislation provides that an effluent must have at least similar water quality, or better, than the water taken. However, the lack of supervision allows that this simply is not fulfilled. Since we use the water resources for multiple uses, it is essential that all parts involved work together to fulfill this gap. For example, it is not interesting for those who use water resources for navigation that the environment is taken of macrophytes, as well as for hydroelectric generation. Similarly, those who use the resource for animal desedentation or human use, water quality is crucial. Therefore, working together for a healthy environment is essential for a better water management. Thus, scientists also need to be together showing its results and how poor water quality generates short- and long-term losses, as well as helping to apply the ecological knowledge to generate new solutions to solve environmental problems. In order to better develop solutions for the Anthropocene issues, the transdisciplinary efforts are essential, seeking a vision of aquatic ecosystems as a whole.

\section{Acknowledgements}

We are grateful for the scientific contribution given by Iollanda Ivanov Pereira Josué. This study was financed in part by the Coordenação de Aperfeiçoamento de Pessoal de Nível Superior Brasil (CAPES) - Finance Code 001. This work was also supported by Conselho Nacional de Desenvolvimento Científico e Tecnológico (CNPq) for Research Productivity Grant provided to FR (473141/2013-2) and AA (310033/2017-9).

\section{References}

ABDEL-SHAFY, H.I. and MANSOUR, M.S. A review on polycyclic aromatic hydrocarbons: source, environmental impact, effect on human health and remediation. Egyptian Journal of Petroleum, 2016, 25(1), 107-123. http://dx.doi.org/10.1016/j. ejpe.2015.03.011.

AHRENS, L. Polyfluoroalkyl compounds in the aquatic environment: a review of their occurrence and fate. Journal of Environmental Monitoring, 2011, 13(1), 20-31. http://dx.doi.org/10.1039/C0EM00373E. PMid:21031178.

ALMEIDA, G.A.D. and WEBER, R.R. Fármacos na represa Billings. Revista de Salud Ambiental, 2009, 6(2), 7-13.

ALVES, R.I., SAMPAIO, C.F., NADAL, M., SCHUHMACHER, M., DOMINGO, J.L. and SEGURA-MUÑOZ, S.I. Metal concentrations 
in surface water and sediments from Pardo River, Brazil: human health risks. Environmental Research, 2014, 133, 149-155. http://dx.doi.org/10.1016/j. envres.2014.05.012. PMid:24949813.

ANASTAS, P.T., HEINE, L.G. and WILLIAMSON, T.C. Green chemical syntheses and processes: introduction. In: P.T. ANASTAS, L.G. HEINE and T.C. WILLIAMSON, eds. Green chemical syntheses and processes. Washington: American Chemical Society, 2000, pp. 1-6.

ANDERSON, D.M., GLIBERT, P.M. and BURKHOLDER, J.M. Harmful algal blooms and eutrophication: nutrient sources, composition, and consequences. Estuaries, 2002, 25(4), 704-726. http://dx.doi.org/10.1007/BF02804901.

BERETTA, M., BRITTO, V., TAVARES, T.M. SILVA, S.M.T. and PLETSCH, A.L. Occurrence of pharmaceutical and personal care products (PPCPs) in marine sediments in the Todos os Santos Bay and the north coast of Salvador, Bahia, Brazil. Journal of Soils and Sediments, 2014, 14(7), 1278-1286. http:// dx.doi.org/10.1007/s11368-014-0884-6.

BONAI, N.C., SOUZA-FRANCO, G.M., FOGOLARI, O., MOCELIN, D.J.C., et al. Distribution of metals in the sediment of the Itá Reservoir, Brazil. Acta Limnologica Brasiliensia, 2009, 21, 245-250.

BRAUSCH, J.M., CONNORS, K.A., BROOKS, B.W. and RAND, G.M. Human pharmaceuticals in the aquatic environment: a review of recent toxicological studies and considerations for toxicity testing. Reviews of Environmental Contamination and Toxicology, 2012, 218(1), 1-99. http://dx.doi.org/10.1007/9781-4614-3137-4_1. PMid:22488604.

BRIX, K.V., ESBAUGH, A.J. and GROSELL, M. The toxicity and physiological effects of copper on the freshwater pulmonate snail, Lymnaea stagnalis. Comparative Biochemistry and Physiology. Toxicology \& Pharmacology : CBP, 2011, 154(3), 261-267. http://dx.doi.org/10.1016/j.cbpc.2011.06.004. PMid:21723419.

CARDOSO, S.J., QUADRA, G.R., RESENDE, N.D.S. and ROLAND, F. O papel dos sedimentos nos ciclos de carbono e poluentes em ecossistemas aquáticos. Acta Limnologica Brasiliensia, 2019, 31, e201. http:// dx.doi.org/10.1590/s2179-975x8918.

CARLILE, B. Pesticide selectivity, health and the environment. Cambridge: Cambridge University Press, 2006. http://dx.doi.org/10.1017/ CBO9780511617874

CARPENTER, S.R. Phosphorus control is critical to mitigating eutrophication. Proceedings of the National Academy of Sciences of the United States of America, 2008, 105(32), 11039-11040. http://dx.doi. org/10.1073/pnas.0806112105. PMid:18685114.
CEREJEIRA, M.J., VIANA, P., BATISTA, S., PEREIRA, T., SILVA, E., VALÉRIO, M.J., SILVA, A., FERREIRA, M. and SILVA-FERNANDES, A.M. Pesticides in Portuguese surface and ground waters. Water Research, 2003, 37(5), 1055-1063. http://dx.doi.org/10.1016/S0043-1354(01)00462-6. PMid:12553980.

CHU, K.W. and CHOW, K.L. Synergistic toxicity of multiple heavy metals is revealed by a biological assay using a nematode and its transgenic derivative. Aquatic Toxicology, 2002, 61(1-2), 53-64. http:// dx.doi.org/10.1016/S0166-445X(02)00017-6. PMid:12297370.

CLEUVERS, M.J. Aquatic ecotoxicity of pharmaceuticals including the assessment of combination effects. Toxicology Letters, 2003, 142(3), 185-194. http:// dx.doi.org/10.1016/S0378-4274(03)00068-7. PMid:12691712.

CLEUVERS, M.J. Mixture toxicity of the antiinflammatory drugs diclofenac, ibuprofen, naproxen, and acetylsalicylic acid. Ecotoxicology and Environmental Safety, 2004, 59(3), 309-315. http:// dx.doi.org/10.1016/S0147-6513(03)00141-6. PMid:15388270.

COLE, J., PRAIRIE, Y.T., CARACO, N., MCDOWELL, W.H., TRANVIK, L.J., STRIEGL, R.G., DUARTE, C.M., KORTELAINEN, P., DOWNING, J.A., MIDDELBURG, J.J. and MELACK, J. Plumbing the global carbon cycle: integrating inland waters into the terrestrial carbon budget. Ecosystems, 2007, 10(1), 172-185. http:// dx.doi.org/10.1007/s10021-006-9013-8.

COSTANZO, S.D., MURBY, J. and BATES, J. Ecosystem response to antibiotics entering the aquatic environment. Marine Pollution Bulletin, 2005, 51(1-4), 218-223. http://dx.doi.org/10.1016/j. marpolbul.2004.10.038. PMid:15757723.

D'AMATO, C., TORRES, J.P.M. and MALM, O. DDT (dicloro difenil tricloroetano): toxicidade e contaminação ambiental - uma revisão. Quimica Nova, 2002, 25(6a), 995-1002. http://dx.doi. org/10.1590/S0100-40422002000600017.

DANTAS, D.D., RUBIM, P.L., OLIVEIRA, F.A., COSTA, M.R., MOURA, C.G.B., TEIXEIRA, L.H. and ATTAYDE, J.L. Effects of benthivorous and planktivorous fish on phosphorus cycling, phytoplankton biomass and water transparency of a tropical shallow lake. Hydrobiologia, 2019, 829(1), 31-41. http://dx.doi.org/10.1007/s10750-0183613-0.

DAUGHTON, C.G. and RUHOY, I.S. Lowerdose prescribing: minimizing "side effects" of pharmaceuticals on society and the environment. The Science of the Total Environment, 2013, 443, 324-337. http://dx.doi.org/10.1016/j.scitotenv.2012.10.092. PMid:23201698. 
DEVI PRASAD, P.V. and DEVI PRASA, P.S. Effect of cadmium, lead and nickel on three freshwater green algae. Water, Air, and Soil Pollution, 1982, 17(3), 263-268. http://dx.doi.org/10.1007/BF00283156.

DOERR-MACEWEN, N.A. and HAIGHT, M.E. Expert stakeholders' views on the management of human pharmaceuticals in the environment. Environmental Management, 2006, 38(5), 853-866. http://dx.doi.org/10.1007/s00267-005-0306-z. PMid:16955232.

\section{ENVIRONMENTAL PROTECTION AGENCY -} EPA. Appendix 1 to 2007 addendum: environmental fate and ecological risk assessment of endosulfan. Washington: United States Environmental Protection Agency, Office of Pesticide Programs, 2007.

FERREIRA, A.P. Caffeine as an environmental indicator for assessing urban aquatic ecosystems. Cadernos de Saude Publica, 2005, 21(6), 1884-1892. http:// dx.doi.org/10.1590/S0102-311X2005000600038. PMid:16410875.

FILSER, J. Ecotoxicology and ecosystems: relevance, restrictions, research needs. Basic and Applied Ecology, 2008, 4(9), 333-336. http://dx.doi.org/10.1016/j. baae.2007.08.009.

FINLAYSON, C., DAVIES, G.T., MOOMAW, W.R., CHMURA, G., et al.The second warning to humanity-providing a context for wetland management and policy. Wetlands, 2018, 11(1), 1-5. http://dx.doi.org/10.1007/s13157-018-1064-z.

FLEEGER, J.W., GUST, K.A., MARLBOROUGH, S.J. and TITA, G.J. Mixtures of metals and polynuclear aromatic hydrocarbons elicit complex, nonadditive toxicological interactions in meiobenthic copepods. Environmental Toxicology and Chemistry, 2007, 26(8), 1677-1685. http://dx.doi.org/10.1897/06-397R.1. PMid:17702342.

FLETCHER, C.L. and MCKAY, W.A. Polychlorinated dibenzo-p-dioxins (PCDDs) and dibenzofurans (PCDFs) in the aquatic environment - a literature review. Chemosphere, 1993, 26(6), 1041-1069. http:// dx.doi.org/10.1016/0045-6535(93)90194-A.

FÖRSTNER, U. and WITTMAN, G.T.W. Metal pollution in the aquatic environment. Berlin Heidelberg, New York, Tokyo, Germany: Springer Verlag, 1983.

GHISELLI, G. Avaliação da qualidade das águas destinadas ao abastecimento público na região de Campinas: ocorrência e determinação dos interferentes endócrinos (IE) e produtos farmacêuticos e de higiene pessoal (PFHP) [tese de doutorado]. Campinas: Instituto de Quimica; Universidade Estadual de Campinas, 2006.

GIBSON, A.M., MORGAN, R.M. and NIKITIN, A.G. The effect of caffeine on the bacterial populations in a freshwater aquarium system. Michigan: Student Summer Scholars, 2009.
GONÇALVES, E. S. Ocorrência e distribuição de fármacos, cafeina e bisfenol-a em alguns corpos hidricos no Estado do Rio de Janeiro [tese de doutorado]. Niterói: Programa de Pós-graduação em Geociências, Universidade Federal Fluminense, 2016.

GRIGGS, D., STAFFORD-SMITH, M., GAFFNEY, O., ROCKSTRÖM, J., OHMAN, M.C., SHYAMSUNDAR, P., STEFFEN, W., GLASER, G., KANIE, N. and NOBLE, I. Policy: Sustainable development goals for people and planet. Nature, 2013, 495(7441), 305-307. http://dx.doi. org/10.1038/495305a. PMid:23518546.

HADJILIADIS, N. Cytotoxic, mutagenic and carcinogenic potential of heavy metals related to human environment. Springer Science and Business Media, 2012.

HALLEGRAEFF, G.M. A review of harmful algal blooms and their apparent global increase. Phycologia, 1993, 32(2), 79-99. http://dx.doi.org/10.2216/ i0031-8884-32-2-79.1.

HAN, S., CHOI, K., KIM, J., JI, K., KIM, S., AHN, B., YUN, J., CHOI, K., KHIM, J.S., ZHANG, X. and GIESY, J.P. Endocrine disruption and consequences of chronic exposure to ibuprofen in Japanese medaka (Oryzias latipes) and freshwater cladocerans Daphnia magna and Moina macrocopa. Aquatic Toxicology, 2010, 98(3), 256-264. http://dx.doi.org/10.1016/j. aquatox.2010.02.013. PMid:20236711.

HARRAD, S. Persistent organic pollutants. John Wiley \& Sons, 2009 . http://dx.doi. org/10.1002/9780470684122.

HATJE, V., PEDREIRA, R.M., REZENDE, C.E., SCHETTINI, C.A.F., SOUZA, G.C., MARIN, D.C. and HACKSPACHER, P.C. The environmental impacts of one of the largest tailing dam failures worldwide. Scientific Reports, 2017, 7(1), 10706. http://dx.doi.org/10.1038/s41598-017-11143-x. PMid:28878243.

HEISLER, J., GLIBERT, P.M., BURKHOLDER, J.M., ANDERSON, D.M., COCHLAN, W., DENNISON, W.C., DORTCH, Q., GOBLER, C.J., HEIL, C.A., HUMPHRIES, E., LEWITUS, A., MAGNIEN, R., MARSHALL, H.G., SELLNER, K., STOCKWELL, D.A., STOECKER, D.K. and SUDDLESON, M. Eutrophication and harmful algal blooms: a scientific consensus. Harmful Algae, 2008, 8(1), 3-13. http://dx.doi.org/10.1016/j. hal.2008.08.006. PMid:28781587.

IMAI, S., KOYAMA, J. and FUJII, K. Effects of $17 \beta$-estradiol on the reproduction of Java-medaka (Oryzias javanicus), a new test fish species. Marine Pollution Bulletin, 2005, 51(8-12), 708-714. http:// dx.doi.org/10.1016/j.marpolbul.2005.02.018. PMid:16291186.

KIM, P., PARK, Y., JI, K., SEO, J., LEE, S., CHOI, K., KHO, Y., PARK, J. and CHOI, K. Effect of chronic exposure to acetaminophen and lincomycin on Japanese medaka (Oryzias latipes) and freshwater 
cladocerans Daphnia magna and Moina macrocopa, and potential mechanisms of endocrine disruption. Chemosphere, 2012, 89(1), 10-18. http://dx.doi. org/10.1016/j.chemosphere.2012.04.006.

PMid:22560975.

KOPRIVNIKAR, J. and WALKER, P.A. Effects of the herbicide atrazine's metabolites on host snail mortality and production of trematode cercariae. The Journal of Parasitology, 2011, 97(5), 822-827. http:// dx.doi.org/10.1645/GE-2814.1. PMid:21554070.

KOUYOUMJIAN, H.H. and UGLOW, R.F. Some aspects of the toxicity of $p, p^{\prime}$-DDT, p, p'-DDE and $\mathrm{p}, \mathrm{p}^{\prime}$-DDD to the freshwater planarian Polycelis felina (Tricladida). Environmental Pollution, 1974, 7(2), 103-109. http://dx.doi.org/10.1016/00139327(74)90077-9.

KÜMMERER, K. Pharmaceuticals in the environment: sources, fate, effects and risks. Springer Science \& Business Media, 2008. http://dx.doi. org/10.1007/978-3-540-74664-5.

LAABS, V., AMELUNG, W., PINTO, A.A., WANTZEN, M., SILVA, C.J. and ZECH, W. Pesticides in surface water, sediment, and rainfall of the northeastern Pantanal basin, Brazil. Journal of Environmental Quality, 2002, 31(5), 1636 1648. http://dx.doi.org/10.2134/jeq2002.1636. PMid:12371181.

LEE, J., JI, K., LIM KHO, Y., KIM, P. and CHOI, K Chronic exposure to diclofenac on two freshwater cladocerans and Japanese medaka. Ecotoxicology and Environmental Safety, 2011, 74(5), 1216-1225. http://dx.doi.org/10.1016/j.ecoenv.2011.03.014. PMid:21489627.

LIAO, C.M., CHEN, B.C., SINGH, S., LIN, M.C., LIU, C.W. and HAN, B.C. Acute toxicity and bioaccumulation of arsenic in tilapia (Oreochromis mossambicus) from a blackfoot disease area in Taiwan. Environmental Toxicology: An International Journal, 2003, 18(4), 252-259. http://dx.doi.org/10.1002/ tox.10122. PMid:12900944.

LOCATELLI, M.A.F., SODRÉ, F.F. and JARDIM, W.F. Determination of antibiotics in Brazilian surface waters using liquid chromatography-electrospray tandem mass spectrometry. Archives of Environmental Contamination and Toxicology, 2011, 60(3), 385-393. http://dx.doi.org/10.1007/s00244-010-9550-1. PMid:20535610.

LOPES, N.P., FREITAS, R.P.D. and ROCHA FILHO, R.C. How many more brumadinhos and marianas will we be faced with yet? Journal of the Brazilian Chemical Society, 2019, 30(4), 681-682. http:// dx.doi.org/10.21577/0103-5053.20190034.

MASON, R.P. Trace metals in aquatic systems. John Wiley and Sons, 2013. http://dx.doi. org/10.1002/9781118274576.
MATTHEWS, G. Pesticides: health, safety and the environment. John Wiley and Sons, 2015. http:// dx.doi.org/10.1002/9781118975923.

MEJÍA-SAAVEDRA, J., SÁNCHEZ-ARMASS, S., SANTOS-MEDRANO, G.E., GÓNZALEZAMARO, R., RAZO-SOTO, I., RICOMARTÍNEZ, R. and DÍAZ-BARRIGA, F. Effect of coexposure to DDT and manganese on freshwater invertebrates: pore water from contaminated rivers and laboratory studies. Environmental Toxicology and Chemistry, 2005, 24(8), 2037-2044. PMid:16152977.

MONTAGNER, C.C. and JARDIM, W.F. Spatial and seasonal variations of pharmaceuticals and endocrine disruptors in the Atibaia River, São Paulo State (Brazil). Journal of the Brazilian Chemical Society, 2011, 22(8), 1452-1462. http://dx.doi.org/10.1590/ S0103-50532011000800008.

MONTAGNER, C.C., JARDIM, W.F., VON DER OHE, P.C. and UMBUZEIRO, G.A. Occurrence and potential risk of triclosan in freshwaters of São Paulo, Brazil - the need for regulatory actions. Environmental Science and Pollution Research International, 2014, 21(3), 1850-1858. http://dx.doi. org/10.1007/s11356-013-2063-5. PMid:23990256.

MONTEIRO, M.A., SPISSO, B.F., SANTOS, J.R.M.P.D., COSTA, R.P.D., FERREIRA, R.G., PEREIRA, M.U., MIRANDA, T.S., ANDRADE, B.R.G. and D'AVILA, L.A. Occurrence of antimicrobials in river water samples from rural region of the State of Rio de Janeiro, Brazil. Journal of Environmental Protection, 2016, 7(02), 230-241. http://dx.doi.org/10.4236/jep.2016.72020.

MOORE, J.W. and RAMAMOORTHY, S. Heavy metals in natural waters: applied monitoring and impact assessment. Springer Science and Business Media, 2012.

MULHOLLAND, K.L. and DYER, J.A. Pollution prevention: methodology, technologies and practices. John Wiley \& Sons, 2010.

OLIVEIRA, R., DOMINGUES, I., GRISOLIA, C.K. and SOARES, A.M. Effects of triclosan on zebrafish early-life stages and adults. Environmental Science and Pollution Research International, 2009, 16(6), 679. 688. http://dx.doi.org/10.1007/s11356-009-0119-3. PMid:19283420.

PARTRIDGE, G.J. and LYMBERY, A.J. Effects of manganese on juvenile mulloway (Argyrosomus japonicus) cultured in water with varying salinity-Implications for inland mariculture. Aquaculture, 2009, 290(3-4), 311-316. http://dx.doi. org/10.1016/j.aquaculture.2009.02.020.

PASCOE, D., CARROLL, K., KARNTANUT, W. and WATTS, M.M. Toxicity of $17 \alpha$-ethinylestradiol and bisphenol A to the freshwater cnidarian Hydra vulgaris. Archives of Environmental Contamination 
and Toxicology, 2002, 43(1), 56-63. http://dx.doi. org/10.1007/s00244-001-0016-3. PMid:12045875.

PAVLOVA, V., NABE-NIELSEN, J., DIETZ, R., SONNE, C., et al.Allee effect in polar bears: a potential consequence of polychlorinated biphenyl contamination. Proceedings of the Royal Society, 2016, 283(1843), 20161883.

PEREIRA, A.L., VASCONCELOS, R.T. and PEREIRA, S.R. Pharmacopollution and Household Waste Medicine (HWM): how reverse logistics is environmentally important to Brazil. Environmental Science and Pollution Research International, 2017, 24(31), 24061-24075. http://dx.doi.org/10.1007/ s11356-017-0097-9. PMid:28929406.

PEREIRA, C.D.S., MARANHO, L.A., CORTEZ, F.S., PUSCEDDU, F.H., SANTOS, A.R., RIBEIRO, D.A., CESAR, A. and GUIMARÁES, L.L. Occurrence of pharmaceuticals and cocaine in a Brazilian coastal zone. The Science of the Total Environment, 2016, 548-549, 148-154. http:// dx.doi.org/10.1016/j.scitotenv.2016.01.051. PMid:26802343.

PESTANA, J.L.T., RÉ, A., NOGUEIRA, A.J.A. and SOARES, A.M.V.M. Effects of Cadmium and Zinc on the feeding behaviour of two freshwater crustaceans: Atyaephyra desmarestii (Decapoda) and Echinogammarus meridionalis (Amphipoda). Chemosphere, 2007, 68(8), 1556-1562. http:// dx.doi.org/10.1016/j.chemosphere.2007.02.053. PMid:17445865.

PICKERING, Q.H., HENDERSON, C. and LEMKE, A.E. The toxicity of organic phosphorus insecticides to different species of warmwater fishes. Transactions of the American Fisheries Society, 1962, 91(2), 175-184. http://dx.doi.org/10.1577/15488659(1962)91[175:TTOOPI]2.0.CO;2.

QIAN, H., LI, J., SUN, L., CHEN, W., SHENG, G.D., LIU, W. and FU, Z. Combined effect of copper and cadmium on Chlorella vulgaris growth and photosynthesis-related gene transcription. Aquatic Toxicology, 2009, 94(1), 56-61. http:// dx.doi.org/10.1016/j.aquatox.2009.05.014. PMid:19570583.

QUADRA, G.R., JOSUÉ, I.I.P., ROLAND, F. and BOZELLI, R. We cannot leave aside the collaborative consumption. International Journal of Waste Resources, 2017b, 7(284), 1-3. http://dx.doi. org/10.4172/2252-5211.1000284.

QUADRA, G.R., ROLAND, F., BARROS, N., MALM, O., LINO, A.S., AZEVEDO, G.M., THOMAZ, J.R., ANDRADE-VIEIRA, L.F., PRAÇA-FONTES, M.M., ALMEIDA, R.M., MENDONÇA, R.F., CARDOSO, S.J., GUIDA, Y.S. and CAMPOS, J.M.S. Far-reaching cytogenotoxic effects of mine waste from the Fundão dam disaster in Brazil. Chemosphere, 2019a, 215, 753-757. http:// dx.doi.org/10.1016/j.chemosphere.2018.10.104. PMid:30347368.

QUADRA, G.R., SILVA, P., PARANAÍBA, J.R., JOSUÉ, I.I., SOUZA, H., COSTA, R., FERNANDEZ, M., VILAS-BOAS, J. and ROLAND, F. Investigation of medicines consumption and disposal in Brazil: A study case in a developing country. The Science of the Total Environment, 2019b, 671, 505-509. http://dx.doi.org/10.1016/j.scitotenv.2019.03.334. PMid:30933805.

QUADRA, G.R., SOUZA, H,O., COSTA, R.D. and FERNANDEZ, M.A. Do pharmaceuticals reach and affect the aquatic ecosystems in Brazil? A critical review of current studies in a developing country. Environmental Science and Pollution Research International, 2017a, 24(2), 1200-1218. http://dx.doi.org/10.1007/s11356-016-7789-4. PMid:27734317.

RAY, B. Climate change: IPCC, water crisis, and policy riddles with reference to India and her surroundings. Lexington Books, 2011.

REEMTSMA, T. and JEKEL, M. Organic pollutants in the water cycle: properties, occurrence, analysis and environmental relevance of polar compounds. John Wiley \& Sons, 2006. http://dx.doi. org/10.1002/352760877X.

RIPPLE, W.J., WOLF, C., NEWSOME, T.M., GALETTI, M., ALAMGIR, M., CRIST, E., MAHMOUD, M.I. and LAURANCE, W.F. World scientists' warning to humanity: a second notice. Bioscience, 2017, 67(12), 1026-1028. http://dx.doi. org/10.1093/biosci/bix 125 .

RISSATO, S.R., GALHIANE, M.S., XIMENES, V.F., DE ANDRADE, R.M., TALAMONI, J.L., LIBÂNIO, M., DE ALMEIDA, M.V., APON, B.M. and CAVALARI, A.A. Organochlorine pesticides and polychlorinated biphenyls in soil and water samples in the Northeastern part of São Paulo State, Brazil. Chemosphere, 2006, 65(11), 1949-1958. http:// dx.doi.org/10.1016/j.chemosphere.2006.07.011. PMid:16919310.

RITTER, W.F. Pesticide contamination of ground water in the United States-A review. Journal of Environmental Science and Health, 1990, 25(1), 1-29. http://dx.doi.org/10.1080/03601239009372674. PMid:2187918.

ROCKSTRÖM, J., STEFFEN, W., NOONE, K., PERSSON, Å., CHAPIN, F.S.I.I.I., LAMBIN, E., LENTON, T.M., SCHEFFER, M., FOLKE, C., SCHELLNHUBER, H.J., NYKVIST, B., DE WIT, C.A., HUGHES, T., VAN DER LEEUW, S., RODHE, H., SÖRLIN, S., SNYDER, P.K., COSTANZA, R., SVEDIN, U., FALKENMARK, M., KARLBERG, L., CORELL, R.W., FABRY, V.J., HANSEN, J., WALKER, B., LIVERMAN, D., RICHARDSON, K., CRUTZEN, P. and FOLEY, J. Planetary boundaries: exploring the safe operating 
space for humanity. Ecology and Society, 2009, 14(2), 1-33. http://dx.doi.org/10.5751/ES-03180-140232.

SALOMONS, W. and FÖRSTNER, U. Metals in the hydrocycle. Springer Science and Business Media, 1984. http://dx.doi.org/10.1007/978-3-642-69325-0.

SANDERS, H.O., HUCKINS, J., JOHNSON, B.T. and SKAAR, D. Biological effects of kepone and mirex in freshwater invertebrates. Archives of Environmental Contamination and Toxicology, 1981, 10(5), 531-539. http://dx.doi.org/10.1007/ BF01054877. PMid:6171211.

SCHINDLER, D.W., HECKY, R.E., FINDLAY, D.L., STAINTON, M.P., PARKER, B.R., PATERSON, M.J., BEATY, K.G., LYNG, M. and KASIAN, S.E. Eutrophication of lakes cannot be controlled by reducing nitrogen input: results of a 37-year wholeecosystem experiment. Proceedings of the National Academy of Sciences of the United States of America, 2008, 105(32), 11254-11258. PMid:18667696.

SCHWARZENBACH, R.P., EGLI, T., HOFSTETTER, T.B., VON GUNTEN, U. and WEHRLI, B. Global water pollution and human health. Annual Review of Environment and Resources, 2010, 35(1), 109-136. http://dx.doi.org/10.1146/annurevenviron-100809-125342.

SEGURA, F.R., NUNES, E.A., PANIZ, F.P., PAULELLI, A.C.C., RODRIGUES, G.B., BRAGA, G.Ú.L., DOS REIS PEDREIRA FILHO, W., BARBOSA JUNIOR, F., CERCHIARO, G., SILVA, F.F. and BATISTA, B.L. Potential risks of the residue from Samarco's mine dam burst (Bento Rodrigues, Brazil). Environmental Pollution, 2016, 218, 813-825. http://dx.doi.org/10.1016/j.envpol.2016.08.005. PMid:27524249.

SMITH, V.H. and SCHINDLER, D.W. Eutrophication science: where do we go from here? Trends in Ecology \& Evolution, 2009, 24(4), 201-207. http://dx.doi. org/10.1016/j.tree.2008.11.009. PMid:19246117.

SMITH, V.H., JOYE, S.B. and HOWARTH, R.W. Eutrophication of freshwater and marine ecosystems. Limnology and Oceanography, 2006, 51(1-2), 351355. http://dx.doi.org/10.4319/1o.2006.51.1_ part_2.0351.

SMITH, V.H., TILMAN, G.D. and NEKOLA, J.C. Eutrophication: impacts of excess nutrient inputs on freshwater, marine, and terrestrial ecosystems. Environmental Pollution, 1999, 100(1-3), 179-196. http://dx.doi.org/10.1016/S0269-7491(99)00091-3. PMid:15093117.

SOBEK, A. and UNDEMAN, E. Tunnel vision in current chemicals management cannot deal with the unknown risk of synthetic chemicals in aquatic systems. Acta Limnologica Brasiliensia, 2019, 31, e106. http://dx.doi.org/10.1590/s2179-975x4219.

SOBEK, A., CORNELISSEN, G., TISELIUS, P. and GUSTAFSSON, Ö.J. Passive partitioning of polychlorinated biphenyls between seawater and zooplankton, a study comparing observed field distributions to equilibrium sorption experiments. Environmental Science \& Technology, 2006, 40(21), 6703-6708. http://dx.doi.org/10.1021/es061248c. PMid:17144299.

STEFFEN, W., CRUTZEN, P.J. and MCNEILL, J.R. The Anthropocene: are humans now overwhelming the great forces of nature. Ambio: A Journal of the Human Environment, 2007, 36(8), 614-621. http:// dx.doi.org/10.1579/0044-7447(2007)36[614:TAA HNO]2.0.CO;2. PMid:18240674.

STEFFEN, W., PERSSON, Å., DEUTSCH, L., ZALASIEWICZ, J., WILLIAMS, M., RICHARDSON, K., CRUMLEY, C., CRUTZEN, P., FOLKE, C., GORDON, L., MOLINA, M., RAMANATHAN, V., ROCKSTRÖM, J., SCHEFFER, M., SCHELLNHUBER, H.J. and SVEDIN, U. The Anthropocene: from global change to planetary stewardship. Ambio, 2011, 40(7), 739761. http://dx.doi.org/10.1007/s13280-011-0185-x. PMid:22338713.

STOCKHOLM CONVENTION. Switzerland: Secretariat of the Stockholm Convention, 2019 [viewed 27 Feb. 2019]. Available from: http://www. pops.int/

TAMBOSI, J.L., YAMANAKA, L.Y., JOSÉ, H.J., MOREIRA, R.F.P.M. and SCHRÖDER, H.F. Recent research data on the removal of pharmaceuticals from sewage treatment plants (STP). Quimica Nova, 2010, 33(2), 411-420. http://dx.doi.org/10.1590/S010040422010000200032 .

TRANVIK, L.J., DOWNING, J.A., COTNER, J.B., LOISELLE, S.A., STRIEGL, R.G., BALLATORE, T.J., DILlON, P., FINLAY, K., FORTINO, K., KNOLL, L.B., KORTELAINEN, P.L., KUTSER, T., LARSEN, S., LAURION, I., LEECH, D.M., MCCALLISTER, S.L., MCKNIGHT, D.M., MELACK, J.M., OVERHOLT, E., PORTER, J.A., PRAIRIE, Y., RENWICK, W.H., ROLAND, F., SHERMAN, B.S., SCHINDLER, D.W., SOBEK, S., TREMBLAY, A., VANNI, M.J., VERSCHOOR, A.M., VON WACHENFELDT, E. and WEYHENMEYER, G.A. Lakes and reservoirs as regulators of carbon cycling and climate. Limnology and Oceanography, 2009, 54(6), 2298-2314. http:// dx.doi.org/10.4319/lo.2009.54.6_part_2.2298.

TUNDISI, J.G. Gerenciamento integrado de bacias hidrográficas e reservatórios: estudos de caso e perspectivas. In: M.G. NOGUEIRA, R. HENRY and A. JORCIN, orgs. Ecologia de reservatórios: impactos potenciais, açóes de manejo e sistemas em cascata. 2. ed. São Carlos: RiMa, 2005. pp. 1-21.

TURGUT, C. The contamination with organochlorine pesticides and heavy metals in surface water in Küçük Menderes River in Turkey, 2000-2002. Environment International, 2003, 29(1), 29-32. 
http://dx.doi.org/10.1016/S0160-4120(02)00127-7. PMid: 12605933.

UNION OF CONCERNED SCIENTISTS - UCS.

World scientists' warning to humanity. Cambridge: UCS, 1992.

VITOUSEK, P.M., MOONEY, H.A., LUBCHENCO, J. and MELILLO, J. Human domination of Earth's ecosystems. Science, 1997, 277(5325), 494-499. http://dx.doi.org/10.1126/ science.277.5325.494.

WELCH, E.B. Ecological effects of waste water: applied limnology and pollutant effects. CRC Press, 2002.
WIT, C.A. An overview of brominated flame retardants in the environment. Chemosphere, 2002, 46(5), 583-624. http://dx.doi.org/10.1016/S0045-6535(01)00225-9. PMid:11999784.

ZAMPARAS, M. and ZACHARIAS, I. Restoration of eutrophic freshwater by managing internal nutrient loads. A review. The Science of the Total Environment, 2014, 496, 551-562. http://dx.doi.org/10.1016/j. scitotenv.2014.07.076. PMid:25108796.

Received: 06 April 2019 Accepted: 18 October 2019 